\title{
EXAMINING POST GRADUDATE THESES IN NURSING IN TURKEY BETWEEN 1980-2015
}

\section{Dilek Büyükkaya Besen}

\author{
Dokuz Eylül Üniversity, Faculty of Nursing, İzmir, Turkey \\ buyukkayabesen@gmail.com
}

\begin{abstract}
The aim of this study is to examine post-graduate thesesin nursing in Turkey between 1980-2015 and to determine the distribution of theses according to years, research types and research topics.

The study was carried out with documental analysis. Theses on the subject area were collected from National Theses Center of Turkish Council of Higher Education. When the research studies are analyzed, what draws attention is that nearly all of them are experimental or quasi-experimental studies. The researchers mostly examined organizational behaviors. Another topic examined in graduate theses was patient care. Most common third experienced subject in field of nursing was nursing education.

According to our results $44,37 \%$ of postgraduate theses in nursing were conducted in 2007-2015, 34,46\% in 2000-2006 and the others before 2000. While 33,33\% of postgraduate theses in nursing focused on patient care in 2000-2006 this proportion increased to 44,18\% in 2007-2015. 258 (38,16\%) of 676 theses focused on patient care, 303 (44,82\%) on organizational behavior and 115(17,01\%) on nursing education. When distribution of research designs used in postgraduatetheses in nursing was analyzed $32,69 \%$ of theses were designed experimental, 18,78\% quasi-experimental and 39,49 non-experimental. 6,80\% of postgraduate theses were descriptive.
\end{abstract}

Keywords: Nursing, post graduate theses, research design, research topic, Turkey.

\section{INTRODUCTION}

Important changes have occurred in nursing education in Turkey as in the rest ofthe world in recent years. Nursing education has been continuing in a complex education system providing different diploma degrees as high school, bachelor, undergraduate, graduate and post graduate [1-3]. In 1972, the Nursing Doctoral Education Program was initiated in Turkey [4]. So much development has been made since that time in the field of nursing education.

While undergraduate education gives students a broad, general education, postgraduate education provides students with more advanced learning in a specialized discipline or sub-discipline. Postgraduate school gives an in-depth understanding such that the student becomes something of an expert in the topic of study. It also teaches advanced skills in such areas as problem solving, 
mathematics, writing, oral presentation, and technology, each as applied to the particular field of study.

Over last ten years as it has been in every field, the number of graduate theses have increased and are continuing to increase with time in Turkey [5]. Now it is possible to come across studies on various different topics. On the other hand the increase of these studies comes the problem of getting them across to their target audiences. As it takes a long time for readers or other researchers to look over these findings, , it has been decided that all of this information must be gathered under one roof, analyzed once more, and that new comments and conclusions must be reached [6].

When post graduated theses in the field of nursing are examined it can be seen that as many theses, most of them are designed experimental, quasi-experimental, mixed and descriptive.

"A research design is the plan of a research study. The design of a study defines the study type (descriptive, correlational, quasi- experimental, experimental, review, meta-analytic) and sub-type (e.g., descriptive-longitudinal case study), research question, hypotheses, independent and dependent variables, experimental design, and, if applicable, data collection methods and a statistical analysis plan. Research design is the framework that has been created to seek answers to research questions" [7].

"Experimental research is a collection of research designs which use manipulation and controlled testing to understand causal processes. Generally, one or more variables are manipulated to determine their effect on a dependent variable. The experimental method is a systematic and scientific approachto research in which the researcher manipulates one or more variables, and controls and measures any change in other variables On the other side quasi experiments resemble quantitative and qualitative experiments, but lack random allocation of groups or proper controls, so firm statistical analysis can be very difficult. Quasi-experimental design involves selecting groups, upon which a variable is tested, without any random pre-selection processes. Descriptive research design is a scientific method which involves observing and describing the behavior of a subject without influencing it in any way" [7].

When postgraduate theses in the field of nursing were examined it was observed that all of them focused on specific topics. The researchers mostly examined organizational behaviors. Another topic examined in graduate theses was patient care. Most common third experienced subject in field of nursing was nursing education.

"Organizational behavior is the study of human behavior in organizational settings, the interface between human behavior and the organization, and the organization itself. It deals with individuals in organization, work groups and behaving of organizations" [8].

Postgraduate theses in the field of nursing focused on organizational behavior examined these topics in health institutes:
$\checkmark$ Stress
$\checkmark \quad$ Individual attitudes and behaviors
$\checkmark$ Role of Ethics
$\checkmark$ Job satisfaction
$\checkmark$ Motivation
$\checkmark$ Health management
$\checkmark$ Organizational Culture 
Most discussed topics by post graduate theses in nursing on patient care were:

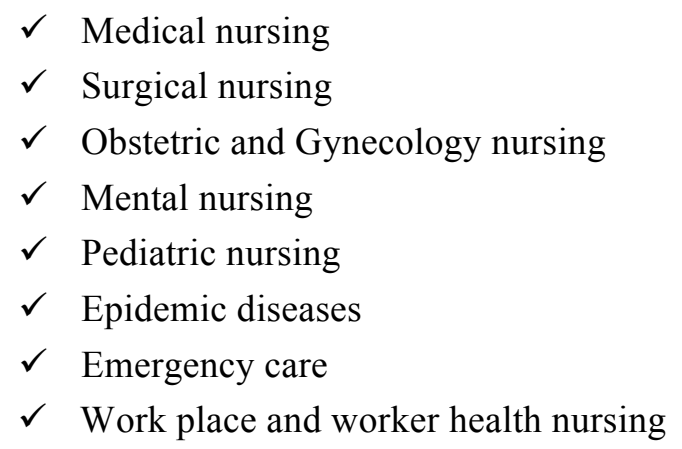

Postgraduate theses in nursing focused on nursing education examined new approaches, assumptions and priorities and problems in nursing education.

\section{METHOD:}

In this study post-graduate theses in nursing between 1980-2015 were examined and distributions according to years, research types and research topics were determined.

The study was carried out with documental analysis. Theses on the subject area were collected from National Theses Center of Turkish Council of Higher Education. 676 theses were investigated. Distribution of theses in nursing according to years was analyzed and results were shown in Table 1.

Table 1.Distribution of postgraduate theses in nursing according to years

\begin{tabular}{|c|c|c|}
\hline Years & $\mathbf{N}$ & $\mathbf{\%}$ \\
\hline $1980-1989$ & 11 & 1,62 \\
\hline $1990-1999$ & 132 & 19,52 \\
\hline $2000-2006$ & 233 & 34,46 \\
\hline $2007-2015$ & 300 & 44,37 \\
\hline Total & 676 & 100 \\
\hline
\end{tabular}

According to Table 1, 44,37\% of postgraduate theses in nursing were conducted in 2007-2015, $34,46 \%$ in 2000-2006 and the others before 2000 .

In Table 2 distribution of post graduate theses in nursing according to topics can be seen. 
Table 2.Distribution of post graduate theses in nursing according to topics

\begin{tabular}{|l|c|c|c|c|c|c|c|c|}
\hline \multirow{2}{*}{ Years } & \multicolumn{9}{|c|}{ Topics } \\
& $\begin{array}{c}\text { Organizational } \\
\text { Behavior }\end{array}$ & \multicolumn{2}{|c|}{ Patient Care } & \multicolumn{2}{c|}{$\begin{array}{c}\text { Nursing } \\
\text { Education }\end{array}$} & \multicolumn{2}{c|}{ Total } \\
\hline & $\mathbf{n}$ & $\mathbf{\%}$ & $\mathbf{n}$ & $\%$ & $\mathbf{n}$ & $\mathbf{\%}$ & $\mathbf{n}$ & $\%$ \\
\hline $\mathbf{1 9 8 0 - 1 9 8 9}$ & 5 & 0,16 & 5 & 0,19 & 1 & 0,01 & 11 & 0,01 \\
\hline $\mathbf{1 9 9 0 - 1 9 9 9}$ & 70 & 23,10 & 53 & 20,54 & 9 & 7,82 & 132 & 19,52 \\
\hline $\mathbf{2 0 0 0 - 2 0 0 6}$ & 111 & 36,63 & 86 & 33,33 & 36 & 31,30 & 233 & 34,46 \\
\hline $\mathbf{2 0 0 7 - 2 0 1 5}$ & 117 & 38,61 & 114 & 44,18 & 69 & 60,00 & 300 & 44,37 \\
\hline Total & $\mathbf{3 0 3}$ & $\mathbf{1 0 0}$ & $\mathbf{2 5 8}$ & $\mathbf{1 0 0}$ & $\mathbf{1 1 5}$ & $\mathbf{1 0 0}$ & $\mathbf{6 7 6}$ & $\mathbf{1 0 0}$ \\
\hline
\end{tabular}

As can be seen from Table 2 while 33,33\% of postgraduate theses in nursing focused on patient care in 2000-2006 this proportion increased to 44,18\% in 2007-2015. $258(38,16 \%)$ of 676 theses focused on patient care, $303(44,82 \%)$ on organizational behavior and $115(17,01 \%)$ on nursing education.

Distributions of research designs used in postgraduate theses in nursing were examined and results were shown in Table 3.

Table 3. Distribution of research designs used in postgraduate theses in nursing

\begin{tabular}{|l|c|c|}
\hline Design of the research & N & \% \\
\hline Experimental & 221 & 32,69 \\
Quasi-experimental & 127 & 18,78 \\
Non experimental & 267 & 39,49 \\
Mixed & 46 & 6,80 \\
Descriptive & 15 & 2,21 \\
Total & $\mathbf{6 7 6}$ & $\mathbf{1 0 0 , 0}$ \\
\hline
\end{tabular}

According to Table 3 when distribution of research designs used in post graduate theses in nursing was analyzed $32,69 \%$ of theses were designed experimental, $18,78 \%$ quasi-experimental and 39,49 non-experimental. $6,80 \%$ of postgraduate theses was descriptive. 
Table 4. Distribution of postgraduate theses in nursing according to research design and years

\begin{tabular}{|l|c|c|c|c|c|c|}
\hline \multirow{2}{*}{ Years } & \multicolumn{5}{|c|}{ Research design } & \\
\cline { 2 - 7 } & Experimental & $\begin{array}{c}\text { Quasi- } \\
\text { experimental }\end{array}$ & $\begin{array}{c}\text { Non } \\
\text { experimental }\end{array}$ & Mixed & Descriptive & Total \\
\hline $\mathbf{1 9 8 0 - 1 9 8 9}$ & 4 & 1 & 6 & 0 & 0 & 11 \\
\hline $\mathbf{1 9 9 0 - 1 9 9 9}$ & 40 & 3 & 77 & 10 & 2 & 132 \\
\hline $\mathbf{2 0 0 0 - 2 0 0 6}$ & 77 & 53 & 79 & 16 & 6 & 233 \\
\hline $\mathbf{2 0 0 7 - 2 0 1 5}$ & 100 & 70 & 103 & 20 & 7 & 300 \\
\hline Total & 221 & 127 & 267 & 46 & 15 & 676 \\
\hline
\end{tabular}

It can be seen from Table 4 that number of non-experimental designs are smaller than number of experimental and quasi-experimental designs in all periods.

\section{DISCUSSION}

After examining postgraduate theses in the field of nursing, we determined that before 1990 the research designs of theseswere mostly non experimental. Use of experimental and quasi-experimental designs in nursing researches began to increase after 2000s. Tel and Sabancioğullarından found compatible results with us [9]. They examined theses in the field of physiciatric nursing and found that $55,5 \%$ of theses were quasi experimental and $35,4 \%$ descriptive. Aslan and friends investigated that $45 \%$ of PhDtheses were experimental and $2 \%$ were descriptive [10]. In a study conducted by Ardahan and Ozsoy on PhDtheses and they stated conflicting results with our study that $45,65 \%$ of theses were descriptiveand $16 \%$ were experimental [11].

A meta analysis conducted by Lee and friends among 1089 postgraduate theses written in 19822010 found out that most of the theses $(51,5 \%)$ were designed experimental, $38,8 \%$ epidemiologic and 5\% descriptive [12]. Shin and friends examined PhDtheses in the field of nursing in 2000-2006 and investigated that of theses $45 \%$ were experimental, $23 \%$ methodological and $17 \%$ descriptive [13]. These results were compatible with ours.

In this study postgraduatetheses in the field of nursing were examined according to years, research types and research topics. It can be seen that number of theses is increased year by year and more scientific methods have begun to be used in the research processes of theses. Also topics of theses converted from job satisfaction, role of ethics, individual attitudes and behaviors, communication, health management and organizational culture to patient care as medical nursing, surgical nursing, epidemic diseases, emergency care and work place and worker nursing.

\section{REFERENCES}

[1] Seven M., Çınar İ., Fidancı B.E.,Akyüz A, Nurses’ Perspective of Distance Post-Graduate Education: A Turkish Study, 7, (2014), 2, pp.652-661

[2] Feeg, V. Doctoral education:why now and why you? Pediatric Nursing. 30 (2004), 1, pp. 8. 
[3] Anderson, C. A., Current strengths and limitations of doctoral education in nursing: are we prepared for the future? Journal of Professional Nursing, 16, (2000) 4, pp. 191-200.

[4] Yavuz M (2004). Nursing doctoral education in Turkey. Nurse Education Today, 24, 553-559

[5] Karasar, N. Scientific Research Method (9th ed.), Nobel Publication Distribution Co., Ankara, Turkey, 1999

[6] Oruç Ş., Teymuroğlu B., 2011, Graduate Theses Studies About Using Material At Social Science, Education, Procedia Social and Behavioral Sciences, 15, (2011), pp.3216-3221

[7] ***, Explorable, Experimental Research https://explorable.com/experimental-research

[8] ***, Wikipedia, https://en.wikipedia.org/wiki/Organizational behavior

[9] Tel S., Sabancıoğullarından S. Psikiyatri Hemşireliği Doktora Tezlerinin Özellikleri , DEUHYO ED, 7, (2014), 3, pp.178-185

[10] Arslan, F., Uzun, Ş., \& Oflaz, F.. Characteristics experienced difficulties and usage of doctoral dissertations in nursing in Turkey. Turkiye Klinikleri J Nurs Sci, 2, (2010), 2, pp.110-112.

[11] Ardahan M, Özsoy S. Türkiye'de Hemşirelik Araştırmalarındaki Eğilimler: Yüksek Lisans ve Doktora Tezleri Üzerine Bir Çalışma. / Gümüşhane University Journal of Health Sciences ,4, (2015), ,4, pp. 516

[12] Lee KJ, Kang Y, Gu MO, Kim K, Kim O, Suh YO, Suh E, Yang S, Lee EH, Lee JH, Choe MA, Hah YS., Analysis of trends and contents of Nursing doctoral dissertation in Korea, $J$ Korean Acad Nurs, 42 (2012) , 2, pp. 302-9.

[13] Shin, H., Sung, K.M., Jeong, S.H., \& Kim, D.R., Trends of doctoral dissertations in nursingscience: focused on studiessubmitted since 2000. Taehan Kanho Hakhoe Chi Journal, 38, (2008), 1, pp. 74-82 